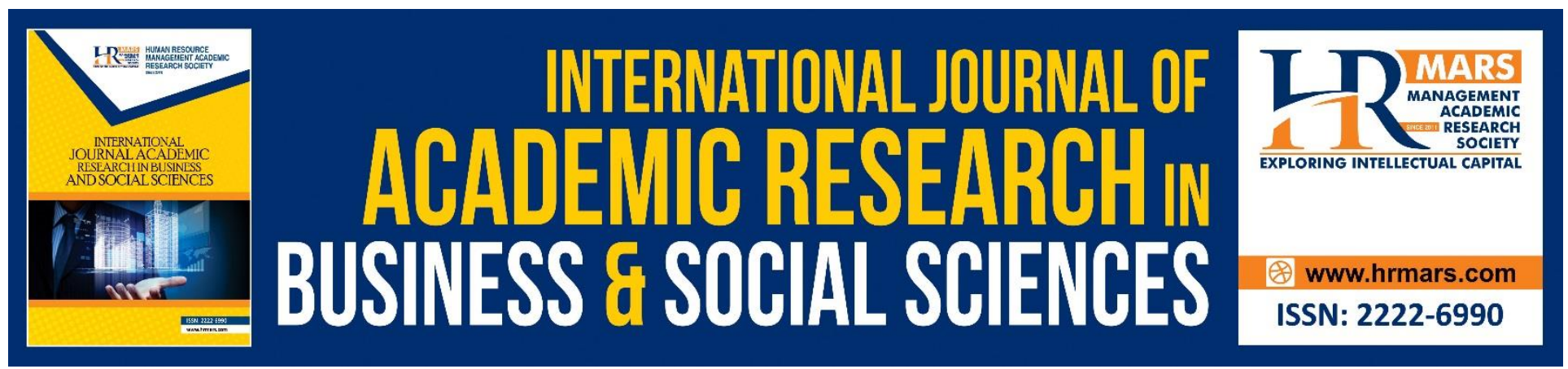

\title{
A Survey of Program MelestariCompany Secretary Bumiputera: Does the Program give an Impact?
}

Mahadir Ladisma @ Awis, Posiah Mohd Isa, Julizaerma Mohamad Khudzari, Yus Aznita Ustadi, Sharifah Faatihah Syed Mohd Fuzi, Syahrina 'Adliana Abdul Halim, Mohd Faiz Ismail, Fadhirul Hisham Aziz, Farihah Hassan, Normarliana Laili

To Link this Article: http://dx.doi.org/10.6007/IJARBSS/v8-i10/4823

DOI: $10.6007 /$ IJARBSS/v8-i10/4823

Received: 21 Aug 2018, Revised: 26 Oct 2018, Accepted: 29 Oct 2018

Published Online: 30 October 2018

In-Text Citation: (Awis et al., 2018)

To Cite this Article: Awis, M. L. @, Isa, P. M., Khudzari, J. M., Ustadi, Y. A., Fuzi, S. F. S. M., Halim, S. 'Adliana A., ... Laili, N. (2018). A Survey of Program Melestari Company Secretary Bumiputera: Does the Program give an Impact? International Journal of Academic Research in Business and Social Sciences, 8(10), 1081-1100.

Copyright: (c) 2018 The Author(s)

Published by Human Resource Management Academic Research Society (www.hrmars.com)

This article is published under the Creative Commons Attribution (CC BY 4.0) license. Anyone may reproduce, distribute, translate and create derivative works of this article (for both commercial and non-commercial purposes), subject to full attribution to the original publication and authors. The full terms of this license may be seen

at: http://creativecommons.org/licences/by/4.0/legalcode

Vol. 8, No. 10, 2018, Pg. 1081 - 1100

http://hrmars.com/index.php/pages/detail/IJARBSS

JOURNAL HOMEPAGE

Full Terms \& Conditions of access and use can be found at http://hrmars.com/index.php/pages/detail/publication-ethics 


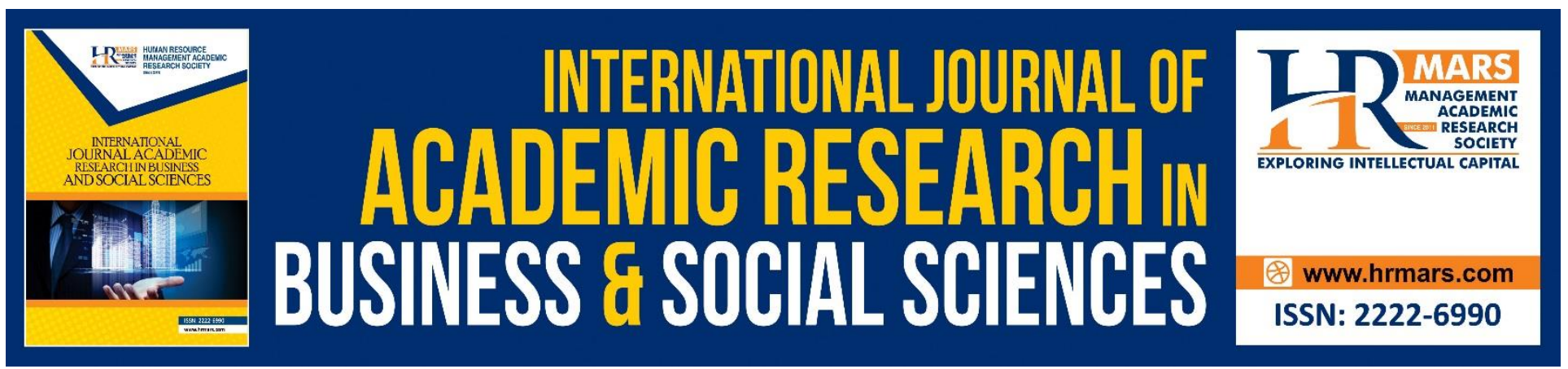

\title{
A Survey of Program Melestari Company Secretary Bumiputera: Does the Program give an Impact?
}

\author{
Mahadir Ladisma @ Awis, Posiah Mohd Isa, Julizaerma Mohamad \\ Khudzari, Yus Aznita Ustadi, Sharifah Faatihah Syed Mohd Fuzi, \\ Syahrina 'Adliana Abdul Halim, Mohd Faiz Ismail, Fadhirul Hisham \\ Aziz, Farihah Hassan, Normarliana Laili
}

Faculty of Administrative Science and Policy Studies, Universiti Teknologi MARA (UiTM), MALAYSIA

\begin{abstract}
The role of company secretary has been receiving great demand recently due to the complexity of management in a dynamic corporate environment. It has become significant and evolve in not just performing administrative duties for a company but also in helping the company to be aligned with the rules and regulation, and the expectation of their shareholders. Therefore, the aims of this paper are; i) to examine the significant roles of company secretary, and ii) to observe the feedback among the participants of Program Melestari Setiausaha Syarikat Bumiputera (PMSSB) which conducted by UiTM and Suruhanjaya Syarikat Malaysia (SSM). As part of the initiatives in supporting this aspiration, SSM together with the Faculty of Administrative Science and Policy Studies (FSPPP) Universiti Teknologi MARA (UiTM) had collaborated to enhance the socio-economic of Bumiputera specifically. This survey employed a cross-sectional survey study where data was gathered just once or in a oneshot manner. The survey had been conducted and designed as exploratory on the expectation among those participating in the PMSSB Series 4 . The survey was conducted during the PSMMB Series 4 involving a total of 27 participants in that program. The data was analyzed using SPSS. The findings reflected that this program is a platform to train the participants as well as a place for them to enhance their knowledge and improve their skills to become competent and qualified company secretary. Uniquely, the PMSSB's contribution in increasing the number of licensed Bumiputera company secretary has been regarded as a medium to enhance good corporate governance practices among corporate citizens in Malaysia. Overall, this program should be continued as it results in positive impact and ability to generate indigenous Bumiputera company secretaries that are competitive.
\end{abstract}

Keywords: Company Secretary, Bumiputera, Company Secretary Bumiputera, Suruhanjaya Syarikat Malaysia, Companies Commission of Malaysia 
INTERNATIONAL JOURNAL OF ACADEMIC RESEARCH IN BUSINESS AND SOCIAL SCIENCES Vol. 8, No. 10, Oct. 2018, E-ISSN: 2222-6990 @ 2018 HRMARS

\section{Introduction}

Managing complexity in a dynamic environment is important. That is why the role of company secretary has become significant and evolve in not just performing administrative duties for a company (Daruwish, 2013). The evolving role of company secretary makes the work tougher, where they have to be firm when advising the board of directors, in which a wrong decision could bring serious repercussions upon them. A misperception among the public regarding the word 'secretary' causes the company secretary profession to be considered as similar to office secretary. Holding different level of tasks and responsibilities, company secretary is an important figure in maintaining the smooth operation of a company. The role of company secretary is vast, from certifying documents up to advising the Board of Directors.

Only qualified persons should be granted to practice as company secretaries. They are the person who advise and ensure the Board of Directors practicing good corporate governance that complies accordingly with the Companies Act 2016 and listing requirements. For that, company secretaries have to be well verse with the regulations and legislatures set under by the regulators about the roles, duties, statutory and compliance matters in governing a company. Therefore, they need to be knowledgeable and also possess a huge amount of experience in order to carry out their work. The importance of having Company Secretary in a company is reflected with the provision in both Companies Act 1965 under Section 139 (1), and newly implemented Companies Act 2016 under Section 235 (1), where both Acts requires every company to have at least one secretary. Besides that, both Acts require every person to become a member of bodies prescribed by the Minister or licensed by the Companies Commission of Malaysia (CCM) to qualify them to act as a Company Secretary. Since every company in Malaysia need to have at least one Company Secretary, the market for this profession is large. This is supported with the fact that almost 1.2 million companies have been incorporated in Malaysia while almost 6.23 million businesses registered, with the latter have the potential to be incorporated.

Therefore, the objectives of this paper are i) to examine the significant roles of company secretary, and ii) to observe the feedback among the participant of Program Melestari Setiausaha Syarikat Bumiputera (PMSSB) conducted by UiTM and Suruhanjaya Syarikat Malaysia (SSM).

\section{Company Secretary in Malaysia}

As the numbers of institutions providing graduates in this area is limited, the job opportunities presented will be higher, whether among in-house public listed or outsource secretarial firms. A person is qualified to act as a company secretary when he or she is licensed by the Registrar of Companies or is a member of a professional body prescribed by the Minister of Domestic Trade, Cooperatives and Consumerism published in the Gazette. The licensing process of company secretaries by Suruhanjaya Syarikat Malaysia (SSM) includes evaluating that the applicant is fit and proper to act as company secretary. The applicant's background, work experience, academic qualifications and knowledge of company law will be assessed by SSM in 2017 (SSM, 2017). Currently, th prescribed bodies are the Malaysian Institute of Chartered Secretaries and Administrators (MAICSA), Malaysian Institute of Accountants (MIA), Malaysian Institute of Certified Public Accountants (MICPA), the Bar 
INTERNATIONAL JOURNAL OF ACADEMIC RESEARCH IN BUSINESS AND SOCIAL SCIENCES Vol. 8, No. 10, Oct. 2018, E-ISSN: 2222-6990 @ 2018 HRMARS

Council of Malaysia, Sabah Law Association, Advocates Association of Sarawak and the Malaysian Association of Company Secretaries (MACS).

\section{Strengthening the Company Secretary of Bumiputera}

In order to enhance their standard of professionalism, company secretaries must continuously undergo courses and training under the Continuing Professional Education (CPE) requirement. For that, SSM has implemented a requirement that licensed company secretaries must regularly attend a minimum number of training sessions or courses in a specified time period before they are allowed to renew their licenses. Till date, the number of company secretary licensed by SSM is 2778 , in which 793 are Bumiputra's (SSM, 2017). In line with the government aspiration to transform Malaysia from developing to developed country by 2020 , the Economic Transformation Program (ETP) has been introduced with the focus of utilizing the competitive advantages such as skilled workforce and prioritizing growth from the identified 12 National Key Areas (NKEAs).

\section{Collaboration between Suruhanjaya Syarikat Malaysia and Universiti Teknologi MARA (UiTM)}

As part of the initiatives in supporting this aspiration, CCM together with the Faculty of Administrative Science and Policy Studies (FSPPP), Universiti Teknologi MARA (UiTM) had formed a collaboration to enhance the socio-economic of Bumiputera specifically. The signing of Memorandum of Understanding (MoU) between CCM and UITM in 2015 had marked the initiation of the Program Melestari Setiausaha Syarikat Bumiputera (PMSSB), where CCM will play the part as the trainer and the financier for this program while UITM will provide the candidates and the venue amongst others. The candidates selected come from the graduates of FSPPP, specifically graduates from Bachelor of Corporate Administration (Hons.). The commitment of both CCM and UITM have been further translated in 2016 where Memorandum of Agreement (MoA) was signed as an effort to increase the number of Bumiputera's licensed Company Secretary.

The impact of increasing the number of Bumiputera licensed Company Secretary can be seen from the economic perspectives. Graduates can develop a sense of entrepreneurship, starting with their own practice, and creating new job opportunities. The license obtained could be their stepping stone to further increase their income level and socio-economic level of Bumiputera. This is parallel with the government's focus in stimulating growth from business services sector as one of the twelve in NKEA. The program also helps increasing the level of skills and knowledge of the graduates in order to compete with an existing players in the industry. By providing comprehensive module in the training program, graduates can become more competent in handling issues related to incorporation until the dissolution of company. Besides that, the program could also serve as a platform to promote good corporate governance in company's operation.

This program comprises of the alumni of Bachelor degree of Corporate Administration students and an estimation of 50 other participants per training session. There are 13 modules presented in the program:

Anatomy of a company:

i) Roles and responsibilities of company secretaries 
ii) Key role-players in a company directors, officers, shareholders and auditors

iii) Managing registered office, statutory books, returns and other documents

iv) Managing company meetings

v) Company incorporation

vi) MyColD

vii) Limited Liability Partnership (LLP)

viii) Company Limited by Guarantee (CLBG)

ix) Foreign Company

$x)$ Interest scheme

xi) Offenses and non-compliance under Companies Act 1965 and Companies Act 2016

xii) Corporate cessation: winding up and striking off

The speaker is from the Companies Commission of Malaysia (SSM) and this program will take 5 days each year and will be held two (2) training sessions.

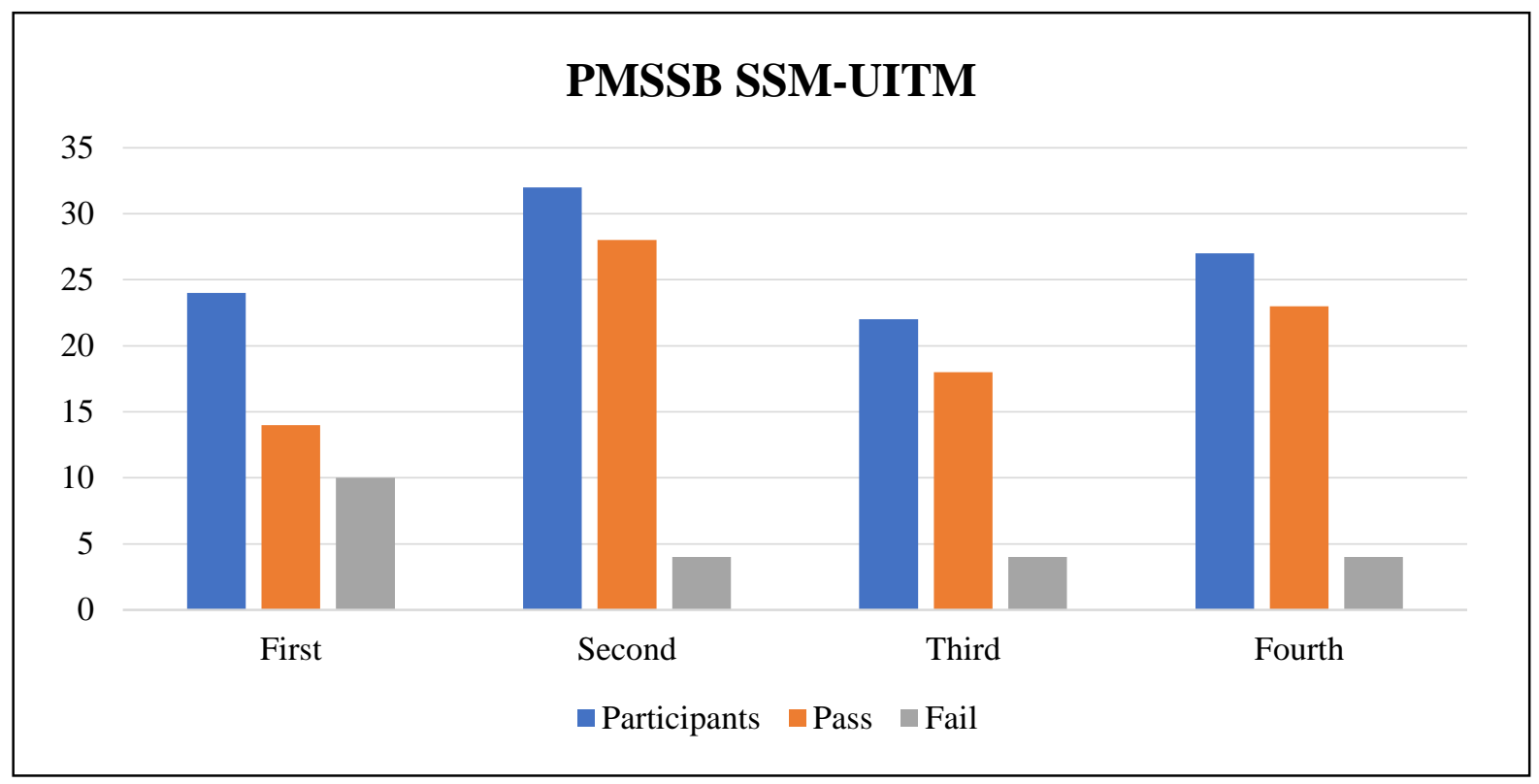

Figure 1: PMMSB SSM-UITM Series 1 - 4

Figure 1 shows the number of participants, total number of passes and failures in the sessions conducted. From the figure, $58.3 \%$ of participants in the first series passes the program while another $41.7 \%$ fails. However, the failure rate decreases significantly in the second series where only $12.5 \%$ of total participants fails, a decrease of $29.2 \%$ from the previous series. The third series on the other hand had recorded the same number of failures even with 10 short participants as compared to the previous one. The passing rate was $81.8 \%$ while the remaining $18.2 \%$ of the participants fails. 
INTERNATIONAL JOURNAL OF ACADEMIC RESEARCH IN BUSINESS AND SOCIAL SCIENCES Vol. 8, No. 10, Oct. 2018, E-ISSN: 2222-6990 ㄷ 2018 HRMARS

However, the latest series recorded an increasing trend in both figures. Failure rates in the fourth session decreases slightly about $3.4 \%$ while the passing rate also increases slightly from $81.8 \%$ to $85.2 \%$.

\section{Definition of University-Industry Collaboration}

Collaboration between university and industry can be defined as relationship, engagement, links or any type of cooperation that involves these two parties. University is the platform where the human capital is nurtured and produced and the industry may need the human capital to join in their organization. As stated by Liew, Tengku Shahdan and Lim (2013), University-Industry Collaborations (UIC) have been the staple of development in science and technology and as such, exist through many forms of collaboration. The presence of universities in the research area is seen as key to the progress of an institution.

Previous studies discussed the collaboration from different perspectives and from different fields. The study conducted by Ankrah and Al Tabbaa (2015) had concluded that the collaborations between university and industry is a kind of engagement that exchanges both tangible and intangible resources between these two parties. Tangible resources are money, fund, equipments while intangible resources can be in term of knowledge, technology and data. Table 1 shows the example of university and industry linkage or relationship.

\section{Table 1}

A Typology of University-Industry Links, From Higher to Lower Intensity

\begin{tabular}{|l|l|l|}
\hline High (Relationships) & Research partnerships & $\begin{array}{l}\text { Inter-organizational arrangements for } \\
\text { pursuing collaborative R\&D, including } \\
\text { research consortia and joint projects. }\end{array}$ \\
\cline { 2 - 3 } & Research services & $\begin{array}{l}\text { Research-related activities commissioned to } \\
\text { universities by industrial clients, including } \\
\text { contract research, consulting, quality } \\
\text { control, testing, certification, and prototype } \\
\text { development. }\end{array}$ \\
\cline { 2 - 3 } & Shared infrastructure & $\begin{array}{l}\text { Use of university labs and equipment by } \\
\text { firms, business incubators, and technology } \\
\text { parks located within universities. }\end{array}$ \\
\hline Medium (Mobility) & $\begin{array}{l}\text { Academic } \\
\text { entrepreneurship }\end{array}$ & $\begin{array}{l}\text { Development and commercial exploitation } \\
\text { of technologies pursued by academic } \\
\text { inventors through a company they (partly) } \\
\text { own (spin-off companies). }\end{array}$ \\
\cline { 2 - 3 } & $\begin{array}{l}\text { Human resource training } \\
\text { and transfer }\end{array}$ & $\begin{array}{l}\text { Training of industry employees, internship } \\
\text { programs, postgraduate training in industry, } \\
\text { secondments to industry of university } \\
\text { faculty and research staff, adjunct faculty of } \\
\text { industry participants }\end{array}$ \\
\hline
\end{tabular}


INTERNATIONAL JOURNAL OF ACADEMIC RESEARCH IN BUSINESS AND SOCIAL SCIENCES Vol. 8, No. 10, Oct. 2018, E-ISSN: 2222-6990 @ 2018 HRMARS

\begin{tabular}{|l|l|l|}
\hline Low (Transfer) & $\begin{array}{l}\text { Commercialization of } \\
\text { intellectual property }\end{array}$ & $\begin{array}{l}\text { Transfer of university-generated IP (such as } \\
\text { patents) to firms (e.g.; via licensing). }\end{array}$ \\
\cline { 2 - 3 } & Scientific publications & $\begin{array}{l}\text { Use of codified scientific knowledge within } \\
\text { industry }\end{array}$ \\
\cline { 2 - 3 } Informal interaction & $\begin{array}{l}\text { Formation of social relationships (e.g,; } \\
\text { conferences, meetings, social networks). } \\
\text { Source }\end{array}$ \\
\hline
\end{tabular}

Source: Adapted from Perkmann and Walsh 2007 as cited in (World Bank, 2013)

\section{Reasons for University and Industry Collaboration}

Collaboration between university and industry has been established a long time ago. It continuously increases as many have seen the benefits of the collaboration between these two parties. Among the benefits of collaboration is skills development such as education and training, the generation, acquisition, and adoption of knowledge through innovation and technology transfer and the promotion of entrepreneurship (World Bank, 2013). These benefits are vital for the development of graduates in order to make them fit into the industry. The collaboration between university and industry may also boost the intention and motivation of staff to carry out more research with the industry (Franco \& Haase, 2015). It also supports the vision and mission of the university to establish link or good relationship with the industry. Staff also claimed that such collaboration may increase academic reputation, obtaining financial resources from the industry and also give an opportunity for academicians to publish a paper in scientific journals and conferences.

Furthermore, the study conducted by Nummi (2006) found that the companies increase their collaboration with the university and industry and to get all the local medical device developers to be involved into their network collaboration. The forms of university-industry collaboration in medical devices development are varied. Most of the collaboration are between the Small Medium Enterprises (SMEs) where they develop their core technologies more often in direct collaboration with the university. Studies have shown that companies that collaborate with universities typically have higher productivity rates than companies that do not have such collaboration. Companies that collaborate also enjoy greater benefits in terms of research and development (R\&D) and are able to produce quality products at a competitive cost (Liew, Tengku Shahdan \& Lim, 2013). Nevertheless, for company secretarial profession, being a professional profession, their existence has to abide by the rules and regulations of the regulatory bodies and their prescribed professional bodies.

\section{Connections between Universities, Regulatory Bodies/Prescribed Professional Bodies and Business Entity}

As such, it can be said that Company Secretary is an intermediate between Companies Commission of Malaysia and the business entity in the country. Therefore, it is important to be able to produce a quality Company Secretary by the professional bodies and also the universities. In UK for example, there were substantial development of higher level vocational programs in universities over the last ten years, often delivered in partnership arrangements with Further Education colleges (Anderson, Bravenboer \& Hemsworth, 2012). 
Work-based learning is actually the best method of teaching and learning when pursuing professional courses. This can be seen by the vast substantial body of researches, reports and case studies such as done by Evans and Guile (2010) which indicated that UK higher education board had moved towards their initiatives to provide degrees that could reflect the employers' needs more closely than the traditional degrees. Work-based degrees expanded the range of vocational programs beyond "first generation" professionally orientated subjects such as architecture, engineering, law, medicine to "second generations" subjects such as business administration and social work.

In Malaysia, Higher Education board have also recognised those needs of collaborating with the International Professional Bodies such as Association of Chartered Certified Accountants (ACCA), Chartered Institute of Management Accountants (CIMA) and Institute of Chartered Secretaries and Administrators (ICSA), in order to be able to produce higher quality of professionals. In public university such as Universiti Teknologi Mara particularly under the Faculty of Administrative Science and Policy Studies, a course structure in line with the qualification program of the Malaysian Institute of Chartered Secretaries and Administrators (MAICSA) has been created since 1997. Over the years, the course of Bachelor of Corporate Administration has produced thousands of graduates that are qualify to embark on their career path as company secretaries. The faculty has a long standing agreement of understanding with both MAICSA and Malaysian Association of Company Secretaries (MACs), of which the agreement with MACs had started since 2003.

Both, MAICSA and MACs are the prescribed bodies as mentioned in section 235 (2) of Companies Act 2016 that shall qualifies a person to act as a Company Secretary. As mentioned earlier, the custodian of Companies Act 2016 was Companies Commission of Malaysia, then it suffices to say that the Government does have a role to play in ensuring the higher quality of independence of a Company Secretary.

\section{Role of Company Commission of Malaysia (CCM)}

As mentioned by Anderson, Bravenboer and Hemsworth (2012), the Coalition Government in the UK is committed to substantially increase the numbers of higher apprenticeship programmes available across a wide range of industry sectors and has been taken by employers and individual learners. Other than that, Evan and Guile (2010) have identified four models of good practice for the development of work-based learning program:

$\begin{array}{lll}\text { Model } 1 & : \begin{array}{l}\text { meshed work based degrees with professional standards and licensing } \\ \text { requirements; }\end{array} \\ \text { Model } 2 & : \begin{array}{l}\text { using tailored work based degrees to support the development of capability } \\ \text { and capacity within coompanies; }\end{array} \\ \text { Model } 3 \quad: \begin{array}{l}\text { using work based degrees to "up skill" and to meet skills shortages in } \\ \text { companies and/or sectors } \\ \text { preparing experienced adults to access a flexible, contract based employment }\end{array} \\ \text { labour market }\end{array}$


INTERNATIONAL JOURNAL OF ACADEMIC RESEARCH IN BUSINESS AND SOCIAL SCIENCES Vol. 8, No. 10, Oct. 2018, E-ISSN: 2222-6990 @ 2018 HRMARS

Therefore, "Program Melestari Setiausaha Syarikat Bumiputera" which has been mutually signed and agreed by the university under the designated faculty and CCM in April 2015 can be said as following Model 1 of Evan and Guile (2010). Under the Companies Act 2016, Section 235 (2) has also stated that besides the prescribed professional bodies, a person who act as a Company Secretary must obtain their license from CCM. It's also reflects the Government's concern and commitment to ensure the highest quality in the profession.

CCM may also provide assistance in term of capital to ensure a successful collaboration between university and industry (Mohd Zaidi \& Salleh, 2013). CCM for an example have contributed financial assistance to the faculty and in return, the faculty will provide number of participants for the program. It is a win-win situation and it is good for the faculty to ensure that the graduates are marketable in the industry.

In addition, Liew, Tengku Shahdan and Lim (2013) supported that financial aid from the government is very important due to the growing need to stay abreast in the multi-faceted business environment. The financial support can be in the form of financial funding and many more.

'Program Melestari Setiausaha Syarikat Bumiputera' is one of the examples by which the regulatory body provides assistance to the university in order to ensure the highest quality of the said profession in the industry. Besides that, the Government through CCM realized the need to have much balance percentage of ethics going into the said profession. Figure 2 illustrates the relationship between university, CCM and the industry.

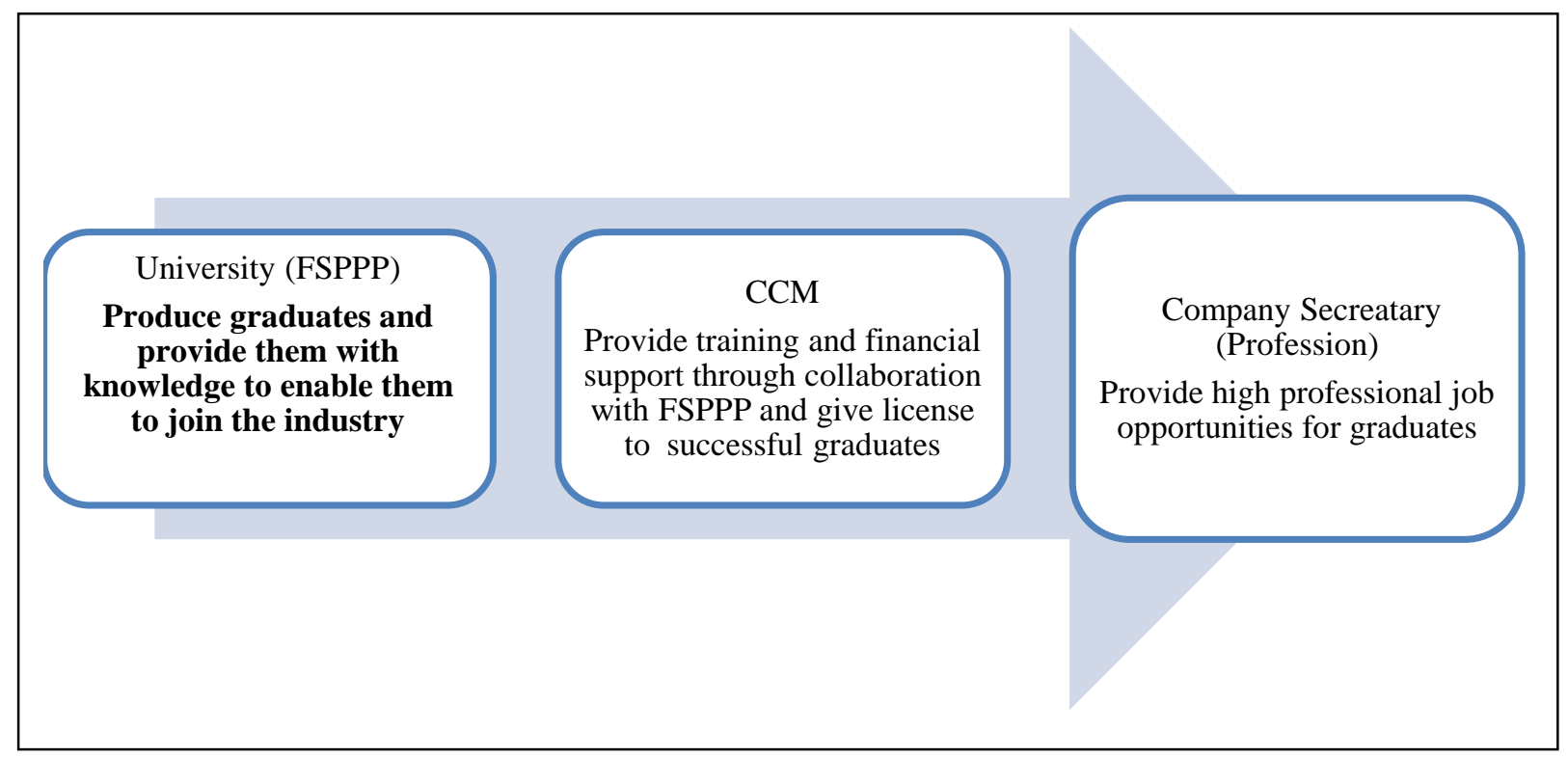

Figure 2: The relationship between FSPPP, CCM and Industry in the Program Melestari Setiausaha Syarikat Bumiputera 
INTERNATIONAL JOURNAL OF ACADEMIC RESEARCH IN BUSINESS AND SOCIAL SCIENCES Vol. 8, No. 10, Oct. 2018, E-ISSN: 2222-6990 @ 2018 HRMARS

\section{The evolving role and scope of Company Secretary especially after Companies Act 2016}

In today's era of globalization where there is a denationalization of countries, organizations have also evolved in their structure. They are mostly engaged in multiple diverse formats in operating across more mature interconnected markets (Kakabadse, Khan and Kakabadse, 2016). These changes are characterised by the competing pressures of integrated government policies and strategic business decentralization.

The company secretary is statutorily defined and driven by the law and its regulations (De Roy, 2015). For instance, this is applied in Malaysia under the statutory law of Companies Act 2016 (CA 2016). Directors who are appointed to manage the company's business may not have the technical knowledge or the time to attend them (Chan Wai Meng, 2017).

In Malaysia, the Companies Act 2016, Section 235 (1) have stated the requirement of appointing at least one company secretary in every company. And the Act further said, a company secretary must be a member of a body prescribed in the Fourth Schedule of the 2016 Act or a person licensed by the Companies Commission of Malaysia, under section 20G of the Companies Commission of Malaysian Act 2001. It shows just how important the roles played by the Company Secretary as one of the important officers (Section 2, Companies Act 2016) in a company to ensure every company abide with the governance provided by regulatory bodies especially Companies Commission of Malaysian as the custodian of the Companies Act 2016. Further, section 235 and 241 of CA 2016 have listed the qualifications needed before a person could act as a company secretary.

This shall be in line with UK's Company's Act (CA 2006) which defines the roles, duties and responsibility of company secretary in sophisticated and highly detailed (De Roy, 2015). By looking at CA 2016, the researcher has seen the shift of role of a company secretary and also the role of the prescribed bodies, where the boundaries of the role vary considerably, as it embraces statutory, managerial, administration and advisory/maintenance functions. This has a certain similarity with Kakabadse, Khan and Kakabadse (2016) when looking into the UK Company code (CA 2006).

Kakabadse, Khan and Kakabadse (2016) have mentioned from the interview and focus groups transcription narratives, they were able to conclude many traits of the Company Secretary emerged, which can be iteratively classified into three major characteristics: technical, commercial and social. In order to ensure that the University students are more marketable and sought after by business entity, the University has agreed to make a collaboration, a joint venture with CCM.

\section{Theoretical Background}

Training program would benefit employers and employees in term of acquisition of new skills and knowledge, able to exercise diligently his/her professional duties and perform complicated tasks (Kucherov \& Manokhina, 2017). Since the new regime of Companies Act 2016 and complex environment in the business market, company secretary should attend continuous professional development programs or any training programs to grasp new knowledge and to better exercise his/her professional duties. Continuing professional development program or training program 
INTERNATIONAL JOURNAL OF ACADEMIC RESEARCH IN BUSINESS AND SOCIAL SCIENCES Vol. 8, No. 10, Oct. 2018, E-ISSN: 2222-6990 @ 2018 HRMARS

conducted by the organization needed to be evaluated to ensure its effectiveness and the quality of that program. The purpose of evaluating training programs is mainly to assess the impact of training program in which it should enhances trainees' abilities after attending them (Guo, 2014). There are various models that can be adapted to evaluate the effectiveness of training program such as Kirkpatrick model, CIRO model, ROI, CIPP model and CIPD model (Sachdeva, 2014). This paper has employed both the Kirkpatrick and CIRO model in assessing the effectiveness of the 'Program Melestari Setiausaha Syarikat Bumiputera' in enhancing trainees' professional development.

Kirkpatrick model consists of four levels of training evaluation namely; reaction, learning, behaviour and results (Kirkpatrick \& Kirkpatrick, 2005). Reaction level measures the trainees' satisfaction towards the implementation of the training program. Whilst, learning level measures the trainees' knowledge and abilities which can be tested before or after the training program. The learning level can be assessed through written test to know how far the trainees are able to grasp knowledge from that training program (Curado \& Martins Teixeira, 2014). Next, the behaviour level to evaluate the changes of trainees' behaviour in which the training program should lead to behavioural changes among the trainees and also to identify the reasons, should no changes occurred after learning (Kirkpatrick \& Kirkpatrick, 2005). The last level is result level. Result level is measuring the impact of training programs in term of financial data or non-financial data. The result can be from various factors such as turnover, return on investment, waste reduction, sales increment and others. This results level is to examine the cost and benefit of conducting the training program, whether the training program with that specific theme should be continued in future. This paper used the first level of that model (reaction level) to measure the trainees' satisfaction in the implementation of PSSMB program.

Another training evaluation model that could be reflected in this paper is CIRO model. The CIRO model consists of four components which are context, input, reaction and outcome evaluation. CIRO model focuses on the objectives of conducting the training program (context), training resources (input), trainees' reaction towards the program's content and approach (reaction) and results of the training (outcome). According to Topno (2012), the context evaluation would assess whether the training's objectives will be able to be achieved or not. Then, the input activity highlights on the design and delivery of training activity which includes the equipment. Trainers' skills are also an important variable to ensure effective delivery of the training activity (Ghosh, Joshi, Satyawadi, Mukherjee, \& Ranjan, 2011). The trainer should provide an explanation of the concepts clearly, use visual teaching aids effectively and communicate course materials effectively.

The reaction evaluation in CIRO model is quite similar to the Kirkpatrick model. The outcome evaluation is assessed at the three levels: immediate, intermediate and ultimate evaluation (Topno, 2012). The outcome immediate level is testing the trainees' knowledge, ability and skills before the trainees return to the job (immediately after finishing the training program), intermediate level focuses on the impact of training program on the job performance and ultimate level assesses the impact of training program towards the organizational performance. The limitation of CIRO model is that it did not measure the behavioural changes like Kirkpatrick model which is important in assessing 
INTERNATIONAL JOURNAL OF ACADEMIC RESEARCH IN BUSINESS AND SOCIAL SCIENCES

Vol. 8, No. 10, Oct. 2018, E-ISSN: 2222-6990 @ 2018 HRMARS

the management training program (Tennant, Boonkrong, \& Roberts, 2002). Both models were adopted by this study and some other evaluation variables also included which are essential to improve the trainees' satisfaction in the future.

\section{Evaluating Components of Program Melestari Setiausaha Syarikat Bumiputera}

The evaluation of this program was focused on four main components namely; program content, program design, program instructor and result, and overall evaluation. Program content was highlighted on the program objectives and the relevancy of the content covered during the program with the trainees' job demand. The satisfaction level of the trainees increased when the continuing professional development program covered well-themed of topics (Guo, 2014). Training need analysis should be directed to ascertain the learning needs of trainees and meet their expectations when attending the program. While designing the program, the organization and training provider (whether internal or external) need to determine the need of trainees and real-life need in order to ensure the program is able to educate new skills (Tennant et al., 2002). Thus, this program content is related to the context and reaction evaluation of CIRO model.

The second evaluating component of this program is program design. This program design discussed the delivery and approach used in the program activity. This component is related to the input evaluation in CIRO model of evaluation. The program design evaluated the effective learning activities and learning environment to support the process of learning among trainees. The andragogy approach of learning should be implemented to teach adult learners. It is due to the fact that they have already possess vast working experience and they are expecting something which can be used for their real-life problems (Parnell \& Procter, 2011). Besides that, the culture of organizational learning through an involvement of the trainee's supervisor and department director can enhance the transfer of knowledge in the organization (Packard \& Jones, 2015). CCM as the regulator ensures the effective function of company secretaries to play their roles by getting involve at the planning stage before the program implementation, during the program and after completion. Thus, effective knowledge transfer could be seen from the side of the regulator and participant of this program.

Program instructor and result is also considered in the evaluation of this program. Assessing program instructors is part of an input evaluation of CIRO model. Trainer attributes could lead to behavioural change and enhance the participant's performance in the organization (Chukwu, 2016). Some trainer attributes are facilitation disposition, provide real-life examples, group work, increase participant involvement, demonstrations and tell stories/illustrations. Facilitation approach will allow for active learning and enhance individual involvement in that learning process (McAllister, Withyman, \& Knight, 2018). Besides, the feedback provided by the participant at the end of the training session lead to improve the trainers' approach for the next session/program (Passmore \& Velez, 2012). The result of this program was evaluated based on immediate outcome evaluation in CIRO model. The immediate outcome of this program was valued at the end of training sessions. Nevertheless, the program outcomes vary among individual depending on the characteristics of the trainees and the context in which they are working with (Crocker, Shields, Venkataramanan, Saywell, \& Bartram, 2016). 
Lastly, other evaluation component at several other factors that might influence the satisfaction of the participants towards the program. Similarly, a research conducted by Ghosh et al. (2011) evaluated the effectiveness of training program offered in term of food served, venue and other facilities provided. According to Curado \& Martins Teixeira (2014), the reaction level of evaluation and overall satisfaction of trainees towards training program can be influenced by three (3) aspects; which are: 1) training is properly planned and organized, support system and adequate facilities; 2 ) perception of the utility of knowledge for future professional work demand; and 3) perception of the program's performance (such as time management, involvement and knowledge transfer).

\section{Methods}

This survey employed a cross-sectional survey study where data was gathered just once or in a oneshot manner. The survey conducted and design as exploratory on the expectation among those participating in the PMSSB Series 4. The survey further elaborated on the extent that PMSSB can benefit the participants towards their career development. The data is presented by using descriptive data using frequency and percentage. The unit of analysis of this survey is the individual who defined as potential company secretary that at least has one-year working experience in secretarial work. The survey was conducted during the PSMMB Series 4 involving the total 27 participants in that program. The data was analyzed using SPSS.

\section{Results}

\section{Profile of Respondents}

The following discussion explains the profile of respondents who were involved in this survey. Table 2 illustrates the gender, age, and experiences of respondents.

Table 2

Profile of Respondents ( $n=27)$

\begin{tabular}{llcc}
\hline & Variable & Frequency & Percent \\
\hline Gender & Male & 8 & 29.6 \\
& Female & 19 & 70.4 \\
\hline Age & 23 & 1 & 3.7 \\
& 24 & 10 & 37.0 \\
& 25 & 6 & 22.2 \\
& 26 & 2 & 7.4 \\
& 27 & 2 & 7.4 \\
& 28 & 3 & 11.1 \\
& 29 & 2 & 7.4 \\
& 30 & 1 & 3.7 \\
\hline Year of Experience & $<2$ years & 21 & 78 \\
& $3-4$ years & 5 & 18 \\
& $>5$ years & 1 & 4 \\
\hline
\end{tabular}


INTERNATIONAL JOURNAL OF ACADEMIC RESEARCH IN BUSINESS AND SOCIAL SCIENCES

Vol. 8, No. 10, Oct. 2018, E-ISSN: 2222-6990 @ 2018 HRMARS

Table 2 above explains the demographic profile. There are 8 (29.6\%) male respondents, and 19 (70\%) female respondents. The age of respondents shows that 10 (37\%) respondents are 24 years old, and $6(22.2 \%)$ respondents are 25 years old. $3(11.1 \%)$ respondents are 28 years old. There are $2(7.4 \%)$ respondents aged 26, 27 and 29 respectively. However, 1 (3.7\%) of the respondent aged 23 and 30 each. There are $21(78 \%)$ of the respondents with more than two years of experience. $5(18 \%)$ within 3 to 4 years and only one (4\%) of the respondent has more than five years of experience.

Table 3 shows the program content. Two questions were asked to the respondents on the objectives and their expectations towards the program.

Table 3

Program Content $(n=27)$

\begin{tabular}{llrc}
\hline \multicolumn{2}{c}{ Variable } & Frequency & Percent \\
\hline I was well informed about the & Agree & 7 & 25.9 \\
objectives of this program & Strongly agree & 20 & 74.1 \\
\hline This workshop lived up to my & Agree & 8 & 29.6 \\
\cline { 2 - 4 } expectations & Strongly agree & 19 & 70.4 \\
\hline \multirow{2}{*}{\begin{tabular}{llll} 
The content is relevant to my \\
\multicolumn{2}{c}{ job }
\end{tabular}} & Agree & 3 & 11.1 \\
\cline { 2 - 4 } & Strongly agree & 24 & 88.9 \\
\hline
\end{tabular}

As stated, Table 3 above explains the content of the program. 20 (74.1\%) respondents indicated strongly agree as they were well informed about the objectives of the program. However, 7 (25.9\%) respondents indicated agreement with the same question. The respondents were also asked on their expectation of the program. 19 (70.4\%) agree that the program have met their expectations, and 8 (29.6\%) respondents indicated agree. The last question asked whether the content of the program is relevant to their job. 24 (88.9\%) indicated strongly agree and $3(11 / .1 \%)$ agree.

Table 4 discusses the program design. These five questions were asked as stated in the table below.

Table 4

Program Design $(n=27)$

\begin{tabular}{|c|c|c|c|}
\hline \multicolumn{2}{|l|}{ Variable } & Frequency & Percent \\
\hline \multirow{2}{*}{$\begin{array}{l}\text { The workshop objective was clear } \\
\text { to me }\end{array}$} & Agree & 8 & 29.6 \\
\hline & Strongly agree & 19 & 70.4 \\
\hline \multirow{2}{*}{$\begin{array}{l}\text { The workshop objective stimulated } \\
\text { my learning }\end{array}$} & Agree & 5 & 18.5 \\
\hline & Strongly agree & 22 & 81.5 \\
\hline \multirow{2}{*}{$\begin{array}{l}\text { The activities in this workshop } \\
\text { gave me sufficient practice }\end{array}$} & Agree & 8 & 29.6 \\
\hline & Strongly agree & 19 & 70.4 \\
\hline \multirow[t]{3}{*}{$\begin{array}{l}\text { The difficulty level of this } \\
\text { workshop was appropriate }\end{array}$} & $\begin{array}{l}\text { Neither agree nor } \\
\text { disagree }\end{array}$ & 1 & 3.7 \\
\hline & Agree & 8 & 29.6 \\
\hline & Strongly agree & 18 & 66.7 \\
\hline
\end{tabular}


INTERNATIONAL JOURNAL OF ACADEMIC RESEARCH IN BUSINESS AND SOCIAL SCIENCES Vol. 8, No. 10, Oct. 2018, E-ISSN: 2222-6990 @ 2018 HRMARS

\begin{tabular}{llrr} 
The place of this workshop was & Neither agree nor \\
appropriate & disagree & 2 & 7.4 \\
\cline { 2 - 3 } & Agree & 7 & 25.9 \\
\cline { 2 - 3 } & Strongly agree & 18 & 66.7 \\
\hline
\end{tabular}

Table 4 illustrates the program design. 19 (70.4\%) respondents indicated strongly agree that the objective of the program was clear, and $8(29.6 \%)$ stated agree. Further, the respondent was asked about whether the objective of the program can stimulate their learning. $22(81.5 \%)$ respondents indicated strongly agree and 5 (18.5\%) indicated agree. Moreover, when asked whether the activities of the program were considered as a sufficient practice, 19 (70.4\%) respondents indicated strongly agree, whereas $8(29.6 \%)$ indicated agree. The respondents were also asked on the difficulty level of the program. 18 (66.7\%) indicated strongly agree, $8(29.6 \%)$ indicate agree and 1 (3.7\%) neither agree nor disagree. The last question on place or location of the program, 18 (66.7\%) indicated strongly agree, 7 (25.9\%) agree and 2 (7.4\%) showed neither agree nor disagree.

The following discussion is about program instructor. Table 5 illustrates the two questions as stated below.

Table 5

Program Instructor and Result ( $n=27)$

\begin{tabular}{|c|c|c|c|}
\hline Variable & & Frequency & Percent \\
\hline \multicolumn{4}{|l|}{ Program Instructor: } \\
\hline \multirow[t]{2}{*}{ The instructor was well prepared } & Agree & 8 & 29.6 \\
\hline & Strongly agree & 19 & 70.4 \\
\hline \multirow[t]{2}{*}{ The instructor was helpful } & Agree & 7 & 25.9 \\
\hline & Strongly agree & 20 & 74.1 \\
\hline \multicolumn{4}{|l|}{ Program Result: } \\
\hline \multirow{2}{*}{$\begin{array}{l}\text { I accomplished the objectives of this } \\
\text { workshop }\end{array}$} & Agree & 8 & 29.6 \\
\hline & Strongly agree & 19 & 70.4 \\
\hline \multirow{2}{*}{$\begin{array}{l}\text { I will be able to use what } \mathrm{i} \text { learned in this } \\
\text { program }\end{array}$} & Agree & 4 & 14.8 \\
\hline & Strongly agree & 23 & 85.2 \\
\hline
\end{tabular}

Table 5 above discusses on program instructor. The respondents were asked about the preparation of the instructor. A total of $19(70.4 \%)$ respondents said that the instructor is well prepared, while 8 (29\%) others stated agree. Further, 20 (74.1\%) and 7 (25.9\%) respondents indicated strongly agree and agree respectively that the instructor was helpful during the program.

This survey was further asking about the result of the program to evaluate whether the participants have met the program objective. 19 (70.4\%) respondents stated strongly agree and 8 (29.6\%) respondents indicated agree on whether they are able to accomplish the objective of the program. In addition, $23(85.2 \%)$ and 4 (14.8\%) of the respondents stated strongly agree and agree respectively on whether they can use what they have learned in this program. 
INTERNATIONAL JOURNAL OF ACADEMIC RESEARCH IN BUSINESS AND SOCIAL SCIENCES

Vol. 8, No. 10, Oct. 2018, E-ISSN: 2222-6990 @ 2018 HRMARS

Finally, this survey asked the participants on overall evaluation of the program. Table 7 illustrates the results.

\section{Table 7}

Overall Evaluation $(n=27)$

\begin{tabular}{|c|c|c|c|}
\hline \multicolumn{2}{|l|}{ Variable } & Frequency & Percent \\
\hline \multirow[t]{2}{*}{ Location which program was held } & Good & 6 & 22.2 \\
\hline & Excellent & 21 & 77.8 \\
\hline \multirow[t]{2}{*}{ Convenience of program day and time } & Good & 7 & 25.9 \\
\hline & Excellent & 20 & 74.1 \\
\hline \multirow[t]{2}{*}{ Overall, how would you rate this program } & Good & 5 & 18.5 \\
\hline & Excellent & 22 & 81.5 \\
\hline Does PMSSB achieve the training objectives? & Yes & 27 & 100.0 \\
\hline $\begin{array}{l}\text { Does PMSSB have increased your knowledge and } \\
\text { skills? }\end{array}$ & Yes & 27 & 100.0 \\
\hline
\end{tabular}

Table 7 states an overall evaluation towards the program. When asked about the program location, $21(77.8 \%)$ and $6(22.2 \%)$ of the respondents indicated excellent and good respectively. Further, 20 (74.1\%) respondents stated excellent and 7 (25.9\%) stated good regarding the day and time the program was organized. For the overall evaluation of the program, 22 (81.5\%) indicated excellent and $5(18.5 \%)$ stated good on how they rated the program. The respondents were also asked about whether the program have achieved the training objectives and increased their knowledge and skills, $27(100 \%)$ respondents stated yes.

\section{Discussion}

\section{Implication and Recommendation for future study}

- Implication shows that the program has significant impact towards strengthening the role of company secretary especially among Bumiputera

- The program was targeted to increase the number of company secretary among Bumiputera. This program was able to give license among CS Bumiputera.

Findings have reflected that this program is a platform to train the participants as well as being a place for them to enhance their knowledge and improving their skills to become a competent and qualified company secretary. Due to the fact that out of 2778 company secretaries licensed by SSM, only 793 of them are Bumiputera. This program has shown a significant impact in strengthening and increasing the number of Bumiputera as a company secretary. The program has also proven that the initiatives through the collaboration between the industry i.e. SSM and the university i.e. UiTM have benefited the profession and industry itself should more Bumiputera licensed secretary could be produced at the end of the program. Through the findings on program content and program design, the participants are prepared and ready to enter the industry to become a competent company secretary. 
Increasing the number of Bumiputera licensed company secretary is also seen as a medium to enhance good corporate governance practices among corporate citizens in Malaysia. The introduction of the Companies Act 2016 and the Corporate Governance Code 2017 (MCCG 2017) demanded a competent company secretary to assist the board. Hence, this program is a place for the newly licensed company secretary to enable themselves to discharge into this role effectively.

To be a good company secretary, the person should have comprehensive knowledge and proficient of the company procedure, well organized, always up to date with the changes in the industry and the most important thing is to have obtained the required qualification. The license company secretary will be equipped with very relevant knowledge and skills through training modules provided in order to fulfil the expectations and the needs of the industry. As they are a company officers whom expected to play advisory roles to the board of directors, they need to be well verse in the aspects of regulatory and compliance.

On the other hand, this program does not only provide the opportunity to become a license company secretary, but also to increase the sense of entrepreneurship among the participants. Over and done with this program, the participants are not only able to achieve individual growth but the national growth as well. It will support one of the government aspirations to become a developed nation and fulfilling one of the NKEA areas to stimulate growth from the business service sector. This profession is special in the sense that it is not only to give license to the Bumiputera to become a company secretary but also to make them an entrepreneur. It is proven whereby one of the benefits of the collaboration between industry and university is the promotion of entrepreneurship (World Bank, 2013).

\section{Recommendation}

Realizing the importance of company secretary roles in enhancing corporate governance practices under Intended Outcome 1.4 of MCCG 2017 whereby the board needs to be supported by a suitably qualified and competent company secretary, it is recommended that regulators as well as professional bodies to be involved in programs similar to this to promote and support the Bumiputera company secretary. Through this kind of training and program, the company secretary will be equipped with a very relevant knowledge and skills that could fulfil the criteria of the industry and also be more prepared to advise the board to comply with the rules and regulations as set by the regulators. Moreover, as the corporate governance practices are not just box ticking, this program is also expected to produce a company secretary who has the willingness to do beyond compliance whereby they will obey the code of ethics and best practices.

Furthermore, it is highly recommended to open up the program to other target groups such as the alumni for other degree programs in UiTM especially, such as the degree holders in accountancy, business administration and law in order to increase the number of company secretary among Bumiputera. Indirectly, it is in line with the government aspiration to transform Malaysia from developing to developed country by 2020 and to enable the enhancement of the socio-economic of Bumiputera specifically as well as increasing the number of entrepreneurs among Bumiputera which 
INTERNATIONAL JOURNAL OF ACADEMIC RESEARCH IN BUSINESS AND SOCIAL SCIENCES

Vol. 8, No. 10, Oct. 2018, E-ISSN: 2222-6990 ㄷ 2018 HRMARS

is parallel with the government focus in stimulating growth from business services sector, as one of the twelve in NKEA.

\section{Limitation}

While this study provides significant findings for this program, there are several limitations that need to be remarked for the purpose of future research. The first limitation is that the findings are only applicable among CS Bumiputera due to the specific target group of this survey. Due to the fact that this program is meant for the alumni of the Bachelor Degree of Corporate Administration, the findings cannot be generalized. It is useful if the research is being replicated to other target groups.

The second limitation is that, although there are numbers of other program for CS, the results of this survey is only representing CS Bumiputera that are conducted between SSM and UiTM. In Malaysia, there are various programs conducted by regulators and professional bodies in order to train those involve in this profession. However, this training program is specific to the one being conducted by SSM and UiTM for the Bumiputera company secretary. Thus, future study may be extended to the other training programs which are meant for this profession.

\section{Conclusion}

Overall, this program should be continued as it results in positive impact and able to generate indigenous company secretary Bumiputera that are competitive. To be a good company secretary, they must be equipped with special skills and technical knowledge since they are the custodian of the company compliance by ensuring their companies abide the legislative requirements and good governance practices. From the overall evaluation, the program has achieved the objectives as well as increasing the knowledge and skill of the participants. The modules provided are also comprehensive with the instructors being competent, well prepared, well-informed and able to deliver the content effectively. The survey of this program believes that this fruitful collaboration will produce high volume of talented license company secretary among Bumiputera as it is indirectly parallel with the government focus in stimulating growth from business services sector, as one of the twelve in NKEA.

\section{Acknowledgement}

This survey was conducted from the Program Melestari Setiausaha Syarikat Bumiputera conducted by Universiti Teknologi MARA (UiTM), Malaysia and Suruhanjaya Syarikat Malaysia.

\section{Corresponding Author}

Mahadir Ladisma @ Awis, PhD

Faculty of Administrative Science and Policy Studies

Universiti Teknologi MARA

70300 Seremban 3, Negeri Sembilan, Malaysia

Email: mahadir.ladisma@gmail.com 
INTERNATIONAL JOURNAL OF ACADEMIC RESEARCH IN BUSINESS AND SOCIAL SCIENCES

Vol. 8, No. 10, Oct. 2018, E-ISSN: 2222-6990 @ 2018 HRMARS

\section{References}

Ankrah, S., \& Al Tabbaa, O. (2015). University-industry collaboration: A Systematic Review. Scandinavian Journal of Management, 396-398.

Anderson, A., Bravenboer, D., \& Hemsworth, D. (2012). The role of universities in higher apprenticeship development. Higher Education, Skills and Work-based Learning, 2(3), 240255.

Chan Wai Meng (2017), Essential Company Law in Malaysia: Navigating the Companies Act 2016, Malaysia: Thomson Reuters Malaysia Sdn. Bhd.

Chukwu, G. M. (2016). Trainer attributes as drivers of training effectiveness. Industrial and Commercial Training, 48(7), 367-373. https://doi.org/10.1108/ICT-02-2016-0013.

Crocker, J., Shields, K. F., Venkataramanan, V., Saywell, D., \& Bartram, J. (2016). Building capacity for water, sanitation, and hygiene programming: Training evaluation theory applied to CLTS management training in Kenya. Social Science and Medicine, 166, 66-76. https://doi.org/10.1016/j.socscimed.2016.08.008.

Curado, C., \& Martins Teixeira, S. (2014). Training evaluation levels and ROI: The case of a small logistics company. European Journal of Training and Development, 38(9), 845-870. https://doi.org/10.1108/EJTD-05-2014-0037

Companies Act (2016), Law of Malaysia Act 777, Percetakan Nasional Malaysia Berhad.

De Roy, K. A. (2015). Exploring the Role of the Office of the Company Secretary in Strengthening Corporate Governance and Administrative Justice in Listed Companies in Ghana(Doctoral dissertation, University of Ghana).

Evans, K., Guile, D., \& Harris, J. (2010). Rethinking work-based learning: For education Professionals and Professionals Who Educate. The SAGE Handbook of Workplace Learning, 149-161.

Franco, M., \& Haase, H. (2015). University-industry cooperation: Researhers' motivation and interaction channels. Journal of Engineering and Technology Management, 46-47.

Ghosh, P., Joshi, J. P., Satyawadi, R., Mukherjee, U., \& Ranjan, R. (2011). Evaluating effectiveness of a training programme with trainee reaction. Industrial and Commercial Training, 43(4), 247255. https://doi.org/10.1108/00197851111137861.

Guo, S. (2014). Developing effective professional development programs: A case study. New Library World, 115(11-12), 542-557. https://doi.org/10.1108/NLW-05-2014-0048.

Kakabadse, A., Khan, N., \& Kakabadse, N. K. (2016). Company secretary: a role of breadth and majesty. Society and Business Review, 11(3), 333-349.

Kirkpatrick, D. L., \& Kirkpatrick, J. D. (2005). Transferring Learning to Behavior: Using the Four Levels to Improve Performance (p. 220). Berrett-Koehler Publishers. Retrieved from https://www.bkconnection.com/static/Transferring_Learning_to_Behavior_EXCERPT.pdf.

Kucherov, D., \& Manokhina, D. (2017). Evaluation of training programs in Russian manufacturing companies. European Journal of Training and Development, 41(2), 119-143. https://doi.org/10.1108/EJTD-10-2015-0084.

Liew, M., Tengku Shahdan , T., \& Lim , E. (2013). Enablers in Enhancing the Relevancy of UniversityIndustry Collaboration. Procedia - Social and Behavioral Sciences , 1889-1991.

Malaysian Code on Corporate Governance (2017). Security Commission Malaysia, Kuala Lumpur. 
INTERNATIONAL JOURNAL OF ACADEMIC RESEARCH IN BUSINESS AND SOCIAL SCIENCES Vol. 8, No. 10, Oct. 2018, E-ISSN: 2222-6990 ㄷ 2018 HRMARS

McAllister, M., Withyman, C., \& Knight, B. A. (2018). Facilitation as a vital skill in mental health promotion: findings from a mixed methods evaluation. Journal of Mental Health Training, Education and Practice, 13(4), 238-247. https://doi.org/10.1108/JMHTEP-05-2017-0036

Mohd Zaidi, O., \& Salleh, M. (2013). University-Industry Collaboration Models in Malaysia . Procedia - Social and Behavioral Sciences, 661-662.

Nummi, J. (2006). University - Industry Collaboration in Medical Devices Development: A Case Study of the Oulu Region in Finland. Local Innovation Systems Project, 20-23.

Packard, T., \& Jones, L. (2015). An outcomes evaluation of a leadership development initiative. Journal of Management Development, 34(2), 153-168. https://doi.org/10.1108/JMD-052013-0063.

Parnell, R., \& Procter, L. (2011). Flexibility and placemaking for autonomy in learning. Educational and Child Psychology, 28(1), 77-88. https://doi.org/10.1002/ace.

Passmore, J., \& Velez, M. (2012). SOAP-M: A training evaluation model for HR. Industrial and Commercial Training, 44(6), 315-325. https://doi.org/10.1108/00197851211254743.

Sachdeva, S. (2014). Effectiveness Evaluation of Behavioural Training and Development Programmes. The SIJ Transactions on Industrial, Financial \& Business Management (IFBM), 2(4), 218-226. Retrieved from https://pdfs.semanticscholar.org/cc45/72ffae286439ecd546cec8279a510b9ed56d.pdf.

Suruhanjaya Syarikat Malaysia (SSM). (2017). Retrieved December 1, 2017, from http://www.ssm.com.my/.

Tennant, C., Boonkrong, M., \& Roberts, P. A. b. (2002). The design of a training programme measurement model. Journal of European Industrial Training, 26(5), 230-240. https://doi.org/10.1108/03090590210424902.

Topno, H. (2012). Evaluation of Training and Development : An Analysis of Various Models. Journal of Bussiness and Management, 5(2), 16-22. Retrieved from www.iosrjournals.org.

World Bank. (2013). Promoting University-Industry Collaboration in developing country. The Innovation Policy Platform, 1-11. 